\title{
La lectura de san Agustín en Ortega y Gasset
}

En este artículo nos proponemos analizar, con detalle, los textos en los que el gran pensador español cita a san Agustín, a lo largo de los 12 volúmenes de su obra publicada, por ahora; se trata de Ortega y Gasset, J., Obras completas. Alianza y Revista de Occidente, Madrid 1983. Por esta edición haremos todas nuestras citas de Ortega con indicación de volumen, en números romanos, seguidos de la página y año, en arábigos. En total, Ortega cita a san Agustín más de 40 veces; es uno de los pensadores más citados por Ortega aunque no se puede comparar la calidad y el número de citas con los clásicos de la filosofía estricta como Platón, Kant o Leibniz para poner sólo algunos ejemplos.

En general, se puede afirmar que Ortega maneja de san Agustín como dos interpretaciones. La vulgar, corriente, tópica y pesimista que habla de san Agustín como del maniqueísmo, platonismo, etc., que es la interpretación standard y más socorrida. Pero también conoce Ortega bien los estudios de otros pensadores modernos que conocen mucho mejor a san Agustín y lo entienden de un modo más actual y más optimista. Estos autores son principalmente: Max Scheler, R. Otto, Geyser, Schneider, Mausbach y E. Przywara entre otros ${ }^{1}$. Erich Przywara, por ejemplo, era como una gran antena de la

1. En la Biblioteca de la Fundación Ortega y Gasset de Madrid encontramos, entre otras, las siguientes obras: Przywara, E., Gott. Fünf Vorträge über das Religiosphilosophische Problem, Oratorium Verlag, München 1926. SCHELER, M., Christentum und Gesellschasft, Neue Geist, Leipzig 1924. Scheider, R., Das Wandelbare Sein. Die Haupthemen der Ontologie Augustinus, Klostermann, Frankfurt, a.M. 1938. Oтто, R., Das Heilige, Trewendt und Granier, Breslau 2 1922. Otтo, R., West-Oestliche Mystik, Kloz-Gotha 1926. MausBach, J., Die Ethik des heiligen Augustinus, Herder, Freiburg i.B. 1909. GEYSER, J., Augustin und die phenomenologischephilosophie der Gegenwart. Mit besonderer Berücksichtigung Max Scheler, Aschendorfscher Verlag, Münster i.W. 1923. Valgan estas pocas obras, junto con el San Agustín de Przywa- 
cultura europea, desde la revista Stimem der Zeit, y publica Debates de actualidad: Ringen der Gegenwart. Gesammelte Aufsätze 1922-1927, Benno Filser, Ausburg 1929. Poco después publica su Augustinus, y la Revista de Occidente se hace traducir importantes escritos de Przywara sobre san Agustín a cargo del antiguo director de Estudio Agustiniano, el P. Lope Cilleruelo; esta obra ve su segunda edición en 1984 en otra editorial: Przywara, San Agustín. Perfil humano y religioso. Cristiandad, Madrid 1984. La lectura por Ortega de estos autores le permite tener un verdadero conocimiento de la actualidad de san Agustín como primer hombre moderno y genio de Europa. Ortega cita a Przywara junto con Max Scheler y Guardini como ejemplo de la cultura católica que convendría hacer hoy y concretamente en España (III, 565, 1927). Pero vayamos con los textos...

\section{San Agustín entre la cultura que salvará al hombre de hoy}

Dice Ortega así: «Los señores Valle-Inclán y Rubén Darío tienen su puesto asegurado en el cielo, como pueden tenerlo Cajal y D. Eduardo Hinojosa. Los que probablmente se irán al infierno - al infierno de la frivolidad, único que hay- son los jóvenes que, sin ser Valle-Inclán ni Rubén Darío, les imitan malamente en lugar de barajar los archivos y reconstruir la historia de España o comentar a Esquilo o a san Agustín. $O$ se hace literatura o se hace precisión o se calla uno» (I, 113,1908).

Habla Ortega de la necesidad que tiene España de verdadera ciencia, pues sin ella no vale decir, como decía Ganivet, que los españoles son abúlicos ya que un pueblo que no tiene ideas claras no puede, nos dice Ortega, tener voluntad fuerte de realizar sus ideales por ser éstos vagos. Llama pues Ortega a una cultura profunda como camino de salvación del hombre y del pueblo. Es ahí cuando remata con su famosa frase: 'O se hace literatura o se hace precisión o se calla uno'. Y entre las cosas precisas que conviene hacer para mejorarse, destaca Ortega el barajar los archivos para hacer una auténtica historia de España o también comentar a Esquilo o a san Agustín. Según Ortega, dejar de lado las ciencias y la auténtica cultura es caer en la pura poesía que es vana e inútil, por eso se ha dicho que cuando Dios quiere destruir a una nación le manda primero una generación de malos poetas. Para Ortega el hombre actual necesita para salvarse del infierno de la frivolidad que él considera como el más peligroso en nuestros días, ya que el frívolo es 'ateo de todo', de una nueva ciencia y de una auténtica cultura. Y piensa Ortega que conocer y comentar a san Agustín forma parte de esta nueva cultura salvadora del hombre

ra, ya citado en el texto pero cuya primera edición llevó a cabo la editorial de la Revista de Occidente, como breve muestra de las lecturas agustinianas de Ortega. 
āctual. Conviene observar que todo esto ya lo dice Ortega en 1908, y que Ganivet aplicaría muy pronto a la salvación de España la consigna agustiniana, del hombre interior en el que habita la verdad, en estos términos: In interiore Hispaniae habitat veritas. Después de grandes discusiones entre europeístas y africanistas también Ortega aceptará, en parte, este camino. Cuando Ortega se pregunta con angustia sobre el problema español: ¿dónde está España?, responderá sin vacilar: en nosotros mismos, en nuestro trabajo, en nuestra mejora humana y moral. Por su parte Ortega, como veremos, comentará muchas veces el texto agustiniano: Noli foras ire, in te ipsum redi, in interiore hominis habitat veritas.

\section{San Agustín como teólogo de la Historia}

Para Ortega la primera teología como la primera filosofía de la Historia es obra de africanos. Se trata de san Agustín y de Abenjaldún: «Conviene que sigamos más al hilo la obra del marroquí. Cronológicamente es la primera filosofía de la historia que se compone. La que podía aspirar antes que ella a este puesto, parto también de una mente africana - san Agustín-, fue propiamente una teología de la historia» (II, 672,1927-1928).

Las historias particulares pasan, son pasajeras: 'Bebe del pozo y deja tu puesto a otros', dice el proverbio árabe. En cambio, la historia profunda, las raíces de la historia, como la vida misma, permanecen siempre. San Agustín va a ser un buceador de ese misterio de la historia que es, al fin y al cabo, nuestro propio misterio. En él nos descubre el enigma de la vida, el gran misterio de Dios, que cruza raudo y silente por la gran escena de la barahúnda humana sujetando con firmeza definitiva las riendas siempre enigmáticas de la historia. Es el misterio que transita entre la vida concreta y la vida suprema.

Para Abenjaldún, el secreto de la historia se encuentra en la relación que hay entre el nomadismo y el sedentarismo. Las revoluciones las hacen los nómadas; la cultura y el Estado los crean los sedentarios. Pero éstos se exponen así a su propia corrupción al instalarse en el progreso y el lujo y la comodidad. El poder corrompe, y el poder absoluto corrompe absolutamente, se ha dicho después. Entonces, aparecen los nuevos nómadas con una nueva revolución. Hay una lucha y hay, más originariamente, una colaboración de todos los pueblos para hacer la historia (II, 675). Pero la vida sedentaria y el poder los corrompen. Las familias reinantes se corrompen (II, 675). Es un hambre vital, de más vida, lo que lanza al hombre a la conquista; un lujo vital que termina por corromper a los pueblos y que pone de manifiesto la famosa afirmación napoleónica de que las revoluciones las hace la vanidad y la libertad es la disculpa. El estancamiento del poder destruye al hombre y sus civilizaciones. Contra eso obra el citado proverbio árabe-nómada (II, 677), en otro caso el cabilismo individualista se consolida y la marcha del pueblo se rompe. 
Es, por tanto, el desierto y su espíritu el que empuja la historia (II, 680). El desierto es monoteísta (II, 683), y desde él Dios empuja la revolución y la utopía. Al nómada la ciudad le huele mal (II, 684). Es el famoso cierto olor a podrido de Ganivet. La ciudad explota al nómada y el nómada asedia, maltrata, sacude y odia la ciudad. Así entre el fatalismo del destino y la libertad presentida el hombre hace la historia. Por su parte, Dios cumple también su tarea...

También san Agustín cree que la historia es peregrinación y es posada. El hombre es peregrino hacia la patria definitiva, hacia otro mundo nuevo, pues, aunque es ciudadano de éste, no tiene aquí su destino permanente. En este mundo el hombre tiende a malearse. Ya la divinidad tuvo que dar un alma al cuerpo para que no se corrompiera. Cuando el hombre se instala y asienta cómodamente, como en el impero romano, también su alma comienza a corromperse. Entonces tienen que surgir los nómadas para barrer la civilización corrompida.

Hoy sabemos, mejor que nunca, que sólo los hombres del desierto pueden construir la ciudad. Sólo el auténtico creyente, el hombre de auténtico desierto, puede construir la verdadera ciudad de Dios que nunca se corrompe ni tiene en esta tierra morada permanente; su morada perpetua es la eternidad.

Finalmente, conviene saber que como Agustín, Ortega fue siempre un nómada de la cultura. Desde Castilla y Andalucía miraba hacia Roma y al África «donde alentó el ímpetu de san Agustín, cuyos rastros iluminan la elocuencia y la curiosidad insaciable por el alma humana de Ortega y Gasset». (Marañón, G., Acto en memoria del catedrático don José Ortega y Gasset. Universidad de Madrid. Facultad de Filosofía y Letras, 18.11.1955, Madrid 1955,64)

\section{El cristianismo vital en san Agustín}

Cuando Ortega describe los diversos momentos del cristianismo en la Historia, se encuentra con un tipo de cristianismo en el cual la vida terrena no vale nada y se ve que lo que realmente importa es Dios y la otra vida. En ese sentido se enfrentan, según Ortega, san Agustín y Nietzsche, como se opone la vida divina que es el supremo valor y la vida humana que es un mal incalculable, puro pecado. Ortega nos refiere así este asunto: «Porque la esencia de todo pecado consiste para el cristiano en que tributamos a nuestra carrera mundanal estimación. Ahora bien; en el deseo, en el placer va incluida una tácita y honda aquiescencia a la vida. El placer, como Nietzsche decía 'quiere eternidad, quiere profunda, profunda eternidad', aspira a perpetuar el delicioso momento y grita da capo a la realidad encantadora. Por eso el cristianismo hace del deseo de placeres, de la cupiditas, el pecado por excelencia Nota 2: Habes apostolum dicentem radicem omnium malorum esse cupiditas (san Agustín). Si, por el contrario, negamos a la vida todo valor intrínseco, y ad- 
vertimos que sólo adquiere justificación, sentido y dignidad cuando se la mediatiza y se hace de ella tiempo de prueba y de eficaz gimnasia para lograr la 'otra vida', cobra un carácter altamente estimable» (III, 183-184, 1923).

En este texto pretende Ortega describir un cristianismo cuyas orientaciones no responden ya a las exigencias de la época actual. Se trata de encontrar una religión de la vida y para la vida. Como dice el Evangelio por boca de Jesús: Yo he venido para que tengan vida y la tengan abundante $(J n 10,10)$. Ortega en este escrito sobre El tema de nuestro tiempo intenta reivindicar el valor de la vida, por sí misma, frente a su permanente instrumentalización. Para ello cita textos de Goethe y Eckhart en los que tanto el escritor como el místico afirman que la vida vale por sí misma. Esto, naturalmente, no decide aún si la vida es la realidad más importante de todas o por encima de todas, pero sí que la vida es la realidad radical y «el texto eterno, la retama ardiendo al borde del camino donde Dios da sus voces» (II, 357, 1914).

El sentido definitivo de la teoría de Ortega hay que verlo en aquella anécdota de la vida de Nietzsche en que se cuenta que el cielo alemán comparado con el italiano no sirve para nada. A lo que Nietzsche responde: Esa es toda mi filosofía y todo lo que yo quise decir en el Así hablo Zarathustra. Se trata de que la vita beata sea vida, no de que esta vida no sea beata (III, 185, 1923). Es lo mismo que decía Unamuno, que nunca pudo aceptar la escuálida inmortalidad que le prometía la teología abstracta escolástica. No se trata de despreciar esta vida ni la otra.

En cuanto a la utilización que hace Ortega de san Agustín en este texto, se trata de la forma corriente en que muchos lo han leído. Es el cliché y el tópico sobre san Agustín que Ortega aprovecha para decir, por contraposición, otra cosa que a él le interesa mucho clarificar. Pero ya encontraremos, enseguida, otras citas de Ortega en las que san Agustín defiende la importancia del cuerpo frente al platonismo griego o el valor de la vida natural sin despreciar la sobrenatural.

Veamos entonces cómo san Agustín tiene una importante estimación de la vida natural y cómo utiliza Ortega la interpretación agustiniana del gran moralista Mausbach. Dice Ortega unas páginas más adelante del pasaje antes comentado: «san Agustín, que había permanecido largo tiempo inmerso en el paganismo, que había visto largamente el mundo por los ojos de los 'antiguos', no podía eludir una honda estimación por esos valores animales de Grecia y Roma. A la luz de su nueva fe, aquella existencia sin Dios tenía que parecerle nula y vacía. No obstante, era tal la evidencia con que ante su intuición se afirmaba la gracia vital del paganismo, que solía expresar su estimación con una frase equívoca: Virtutes ethicorum splendida vitia 'Las virtudes de los paganos son vicios espléndidos'. ¿Vicios? Entonces son valores negativos. ¿Espléndidos? Entonces son valores positivos. Esta valoración contradic- 
toria es lo más que se ha podido obtener para la vida. Su gracia invasora se impone a nuestra sensibilidad; pero, a la vez, nuestra aprobación nos sabe a pecado. ¿Por qué no será pecado decir que el Sol ilumina, y, en cambio, lo es pensar que la vida es espléndida, que va estibada hasta los bordes de valores suficientes, como las naos de Ofir bogaban cargadas de perlas? Vencer esta inveterada hipocresía ante la vida es, acaso, la alta misión de nuestro tiempo") (III, 191, 1923) 'Ortega, después de traducir la frase latina citada, al parecer, de san Agustín , añade en nota: "Como es sabido, no se puede encontrar en sus obras esta fórmula, desde siempre atribuida a san Agustín, pero toda su producción la parafrasea. Véase Mausbach: Die Ethik Augustinus» ${ }^{2}$.

En este texto, lo primero que vemos es que Ortega ha usado la obra de Mausbach sobre san Agustín. Y vemos también cómo a san Agustín se le va el alma hacia esos valores humanos y vitales del paganismo. Aquí san Agustín confirma su honda estimación del hombre natural y su solidaridad con toda la humanidad según el conocido dicho de Terencio tantas veces citado: 'Homo sum, humani nil a me alienum puto' (Soy hombre y nada humano me es ajeno) ${ }^{3}$. Para todo ello, no obstante, san Agustín hará intervenir a Dios y esa es su gran diferencia. Pero aun así, el panorama ha cambiado substancialmente, ya que frente a la lectura anterior en que todo es maldad, se admite - paradójicamente - una cara nueva de la realidad, defectuosa por un lado pero espléndida por otro, como nos dice Ortega. Según este autor hay que avanzar decididamente en esta dirección positiva de la vida y del hombre. Esto ocurre claramente en un texto agustiniano citado un poco más adelante. Cuando habla Ortega de 'La deshumanización del arte' actual, de la iconoclastia que se produce en el arte nuevo contra las imágenes y las formas vivas, recuerda Ortega que en determinadas religiones se prohíben las imágenes divinas. A continuación, afirma Ortega que el arte actual siente 'verdadero asco hacia las formas vivas o de los seres vivientes'. Y añade: «Sería más que interesante inves-

2. MAUSBACH, J., Die Ethik des heiligen Augustinus, Herder, Freiburg i.B. 1909. Esta obra fue muy utilizada por Ortega y hay muchas cosas subrayadas en ella cuyo contenido, en substancia o a la letra, aparece en los escritos de Ortega, sobre todo en los problemas de ética. Si el profesor Muñoz Alonso hubiera conocido la biblioteca de Ortega no hubiera cometido la imprudencia de querer enseñarle a Ortega el título y el lugar de edición de esta obra, como intenta hacer en: Muñoz Alonso, A., San Agustín en la obra de Ortega y Gasset, Augustinus, 1 (1956) 59, nota (15). Todo este artículo es muy critico con Ortega según era costumbre por esa época, con pocas excepciones, en España. Es también un escrito limitado a los 6 vols. publicados hasta ese momento. Ortega conocía la teología alemana bastante mejor que sus oponentes, en particular el grupo de Marburgo, y por eso había leído a Bultmann y a K. Barth, cosa que muy pocos españoles habían hecho.

3. Terencio, Heautontimoroumenos, 1,1,75-77. Citado por san Agustín en la Carta 155, IV, 14. La frase: Virtutes ethnicorum splendida vitia, parece ser una paráfrasis de un autor posterior a san Agustín sobre el pasaje agustiniano de La Ciudad de Dios, XIX, 25. 
tigar con toda atención las erupciones de iconoclasia que una vez y otra surgen en la religión y en el arte. En el arte nuevo actúa evidentemente este extraño sentimiento iconoclasta y su lema bien podía ser aquel mandamiento de Porfirio, que, adaptado por los maniqueos, tanto combatió san Agustín: Omne corpus fugiendum est. Y claro es que se refiere al cuerpo vivo. ¡Curiosa inversión de la cultura griega, que fue en su hora culminante tan amiga de las formas vivientes!» (III, 378, 1925).

Vemos aquí cómo san Agustín aparece liberado del cliché tradicional de oculto maniqueísmo. Tampoco se cita el neoplatonismo como aceptado por él, que es otro tópico muy socorrido y obviado ahora por Ortega. Por el contrario se ve la oposición de san Agustín a Porfirio como transmisor de la cultura neoplatónica griega. Y queda un san Agustín que vemos como defensor de lo vital, de los seres vivientes, del cuerpo vivo que es todo bueno según lo proclama la fe cristiana creacionista. De paso, ofrece también Ortega una reinterpretación de la cultura griega que habría sido en sus mejores momentos cultivadora de lo vital. Y no hay duda de que eso va muy en la dirección de lo dionisíaco en Grecia tan ensalzado por Nietzsche.

Dentro de la fe vital agustiniana no cabe duda que destaca, con singular relieve, el sentido agustiniano del amor. Ortega recurre clamorosamente a la experiencia agustiniana cuando tiene que hablar del amor. Dice así: «San Agustín, uno de los hombres que más hondamente han pensado sobre el amor, tal vez el temperamento más gigantescamente erótico que ha existido, consigue a veces librarse de esta interpretación que hace del amor un deseo o apetito. Así dice en lírica expresión: Amor meus pondus meum; illo feror quocumque feror, 'Mi amor es mi peso; por él voy dondequiera que voy'. Amor es gravitación hacia lo amado» $(\mathrm{V}, 555,1926)$.

El amor, para Ortega, no es principalmente deseo posesivo. El amor lleva, por el contrario, a darse, a entregarse generosamente a la realidad amada. En ese sentido, el amor es una 'divina manía', es la locura de darse. «San Agustín vio sagazmente este ponderar espontáneo hacia un objeto que es característico del amor: Amor meus, pondus meus: illo feror, quocumque feror. ('Mi amor es mi peso: por él voy dondequiera que voy')» (V, 580, 1926).

$\mathrm{El}$ amor nos saca de quicio, nos hace salir de nosotros mismos y nos traslada a la que juzgamos ser la verdadera realidad, aquella que merece realmente, ahora, la pena. Por el amor llegamos a ella. Y cuando se trata de Dios también nos acercamos a Él, no 'andando sino amando' nos dice san Agustín. Y nos dice Ortega: «No se puede ir al Dios que se ama con las piernas del cuerpo, y, no obstante, amarle es estar yendo hacia Él. En el amar abandonamos la quietud y asiento dentro de nosotros, y emigramos virtualmente hacia el objeto. $\mathrm{Y}$ ese constante estar emigrando es estar amando» (V, 556, 1926).

Ése es el 'estado de gracia', feliz y encantado, común al enamorado y al 
místico. Con el corazón lleno de amor: «Al caminar entre las cosas nos sentimos ingrávidos. Como si hubiese dos mundos de dimensiones distintas, pero compenetrables, el místico vive en el terrenal sólo en apariencia; donde verdaderamente está es en el otro, región aparte que habita él solo con Dios. Deum et animam. Nihilne plus? Nihil omnino dice san Agustín. Y lo mismo el enamorado transita entre nosotros, sin que valgamos para otra cosa que para gozar la periferia de su sensibilidad. Él tiene, de antemano y - cree- para siempre, la vida resuelta» $(\mathrm{V}, 590,1926)$.

El corazón agustiniano nos llama hoy de nuevo y nos invita a pensar nuevamente en el amor y, sobre todo, a amar profundamente como lo hizo Agustín. Es él ese corazón gigante que se ofrece como símbolo de amor a toda la humanidad. Cuando Ortega nos habla de lo gigantesco, como lo hace a propósito de san Agustín en (V, 555), se refiere siempre -igual que cuando nos habla de lo gigantesco en el arte de Miguel Ángel o en la filosofía de Giordano Bruno- a algo que es profundamente humano y a la vez oceánicamente divino. $Y$ a eso nos llama hoy san Agustín de nuevo: a ser divinamente humanos y humanamente divinos, es decir, quiere que nos dejemos llevar siempre por un auténtico amor, por el Amor. Como Dios en la plenitud del amor se hizo verdaderamente hombre y como Cristo que amó absolutamente, incondicionalmente, fue a la vez hombre y Dios, a esa misma vida, divina y plenamente humana, estamos llamados todos. Tal es el destino del hombre y el sentido definitivo de todo amor. Así el creyente, recibe de nuevo todas las cosas en plenitud, en la plenitud de Dios, como nos recuerdan Eckhart y san Juan de la Cruz (V, 590, 1926).

En esa dinámica del amor, Ortega entiende la religión como una gran amistad. A Dios, nos advierte Ortega, sólo podemos aproximarnos como nos acercamos a un amigo. Veamos este hermoso texto: «Debe hacernos meditar el hecho de que Dios sea tan silencioso. ¿Qué bien guarda su secreto! Tal vez es tan dramáticamente mudo porque sabe demasiado sobre nuestro interior y una sola palabra reveladora de lo que piensa de nosotros nos aniquilaría. Certísimo es, por otra parte, que no hay otra manera de acercarse a él sino como al amigo, mediante una 'explicación'. Esta consiste en decirse cada cual a sí mismo algo de lo que Dios le diría, pero correcto, calla; confesándonos la verdad sobre nosotros mismos. Símbolo de esto es la confesión, y no sorprende que las 'Confesiones' de san Agustín no sean otra cosa que la guía de su itinerario hasta Dios» (II, 632, 1927).

Advierte Ortega, previamente, que el silencio es la mayor sabiduría, según el proverbio oriental y recuerda que, como decía Nietzche, la medida del saber de una persona se debe hacer por su capacidad de silencio. Es la vida humana misterio y secreto. A veces secretos a voces... Y por eso los amigos cuando ya no pueden decirse las cosas claramente, en confianza, se van callando 
poco a poco y van creciendo en soledad y distancia. Si han de encontrarse de nuevo se deben dar una explicación de su anterior silencio. Según Ortega, Dios calla porque si nos dijera nuestra verdad, ya que él nos conoce a fondo, nos aniquilaría. Ese saber callar tanto, ante la libertad humana, es la gran sabiduría de Dios y su gran secreto sobre el mundo y el destino humano. Cuando el hombre se encuentra con Dios de nuevo necesita darle una explicación de amigo. Mientras, Dios, siempre respetuoso con el hombre, calla misteriosamente. Las Confesiones de san Agustín son el ejemplo más fehaciente, para la humanidad, de ese delicado silencio de Dios ante el misterio del hombre y su libertad. Y, a la vez, la explicación entre amigos, Dios y Agustín, más gozosa y profunda que ha dado el hombre ante ese reencuentro ejemplar protagonizado por Dios y san Agustín.

Es tremenda esa frase de Ortega de que a Dios no hay otra manera de acercarse 'sino como al amigo'. Laín Entralgo verá en ella una prueba de que Ortega - pensador no confesional pero también religioso- como Martín Buber y G. Marcel, y otros muchos, «coinciden en considerar a Dios como Tú soberano e infinito» (Laín Entralgo, P., Teoría y realidad del otro, II, Madrid 1968, 2a,219).

\section{San Agustín y el hombre moderno}

Desde que A. Harnack proclamara a san Agustín como el primer hombre moderno, la idea no se ha parado de repetir. Ortega también habla en varias ocasiones de ello, ya con motivo del problema romántico según veremos inmediatamente, o para subrayar el tema de la interioridad, la subjetividad o el yo, como definición básica de la modernidad.

Cuando habla Ortega del talante romántico, que tanto le disgustaba, nos advierte cómo éste no se relaciona propiamente con la realidad y le acusa de carecer plenamente del auténtico deseo de claridad y de objetividad. Incluso cuando se refiere a la Naturaleza y al paisaje, el carácter romántico lo utiliza para abismarse en sí mismo y dirigirse a su ensimismamiento. Dice Ortega así: «Sabido es que fue Petrarca acaso la primera criatura que cultivó el alpinismo con intención contemplativa. Subió, en efecto, al monte Ventoso, y cuando llegó a lo alto su impresión fue tal, que -ingenuamente nos lo refiere- no se le ocurrió sino ponerse a leer las 'Confesiones' de san Agustín, que llevaba en la faltriquera, y caer en profunda meditación sobre su destino. La anécdota es simbólica. El panorama, apenas entrevisto, obtura la visión misma, rechaza al hombre hacia dentro de sí y le incita a sumirse más que nunca en su íntimo elemento. Esto es, en rigor, lo que el romántico busca al rozarse con los paisajes: más que verlos a ellos, contemplar los remolinos que en su alma apasionada y líquida forma la piedra que cae de fuera» (II, 604, 1927).

Este texto nos indica varias cosas. En primer lugar aparece una profunda 
relacción entre mundo interior y mundo exterior. Nos dice también que, para el hombre romántico, el mundo es como una disculpa de su narcisismo, así que el ecologismo parece muy viejo. Nadie niega hoy algún romanticismo, para bien o para mal, en el ecologismo actual. Por otra parte, vemos que para este gran hombre que fue Petrarca las Confesiones de san Agustín eran libro de bolsillo y cabecera. Esta descripción de Ortega también nos lleva a pensar en el final de Meditaciones Cartesianas de Husserl. Allí el gran pensador, padre de los existencialistas, nos dice que el hombre actual se ha perdido en el mundo y que hace falta perder de nuevo, en cierta manera, el mundo para recuperar al hombre. En ese pasaje final de su obra cita Husserl la conocida expresión agustiniana: Noli foras ire, in te ipsum redi, in interiore hominis habitat veritas. Como es sabido san Agustín intentó las dos cosas: Salvar el hombre y salvar el mundo. Ortega nos invita en este pasaje a recuperar el mundo. Quizá hoy sea más necesario rescatar al hombre perdido en el mundo, pero sin romanticismo ni narcisismo, pues el mundo también tiene sus derechos. Por otra parte, el deseo de objetividad y claridad que tanto amó Ortega en nada se opone a la interioridad, por eso finalmente también Ortega habría aceptado la consigna de inspiración agustiniana lanzada por Ganivet: In interiore Hispaniae habitat veritas; pero si queremos descubrirla, nos añadirá Ortega, no nos olvidemos del estudio, del esfuerzo y del trabajo. Ciertamente el hombre, y el pueblo, moderno es el protagonista de su historia pero eso obliga inevitablemente a poner los medios y las costas, como decía A. Brunner.

El hombre moderno padece también el mal del escepticismo. Al analizar Ortega la posición del pensamiento antiguo con respecto al problema de la verdad nos recuerda que la vida en la antigüedad no padeció desencanto hasta bastante tarde. Sólo a la caída de los imperios surge la cultura de la desesperación y la necesidad de buscar una nueva tabla de salvación para paliar la catástrofe. Hasta entonces, el problema del conocimiento no era una cuestión agobiante como hoy. «Esta inquietud inicial y primaria del alma moderna, que le lleva a preguntarse una y otra vez si será posible la verdad, hubiera sido incomprensible para un meditador antiguo. El propio Platón, que es, con César y san Agustín, el hombre antiguo más próximo a la modernidad, no sentía curiosidad alguna por la cuestión de si es posible la verdad. De tal suerte le parecía incuestionable la aptitud de la mente para la verdad que su problema era el inverso, y se preguntaba una vez y otra: ¿Cómo es posible el error?» (IV, 28, 1924).

En este texto Ortega afirma que Platón, san Agustín y César son los tres hombres más próximos a la modernidad. Más adelante Ortega añadirá que en el caso de san Agustín nos encontramos con el único pensador meridional que no construye el yo y la evidencia como los demás, sino que se adelanta a la modernidad. Esos pensadores construían la evidencia a partir de lo corporal y 


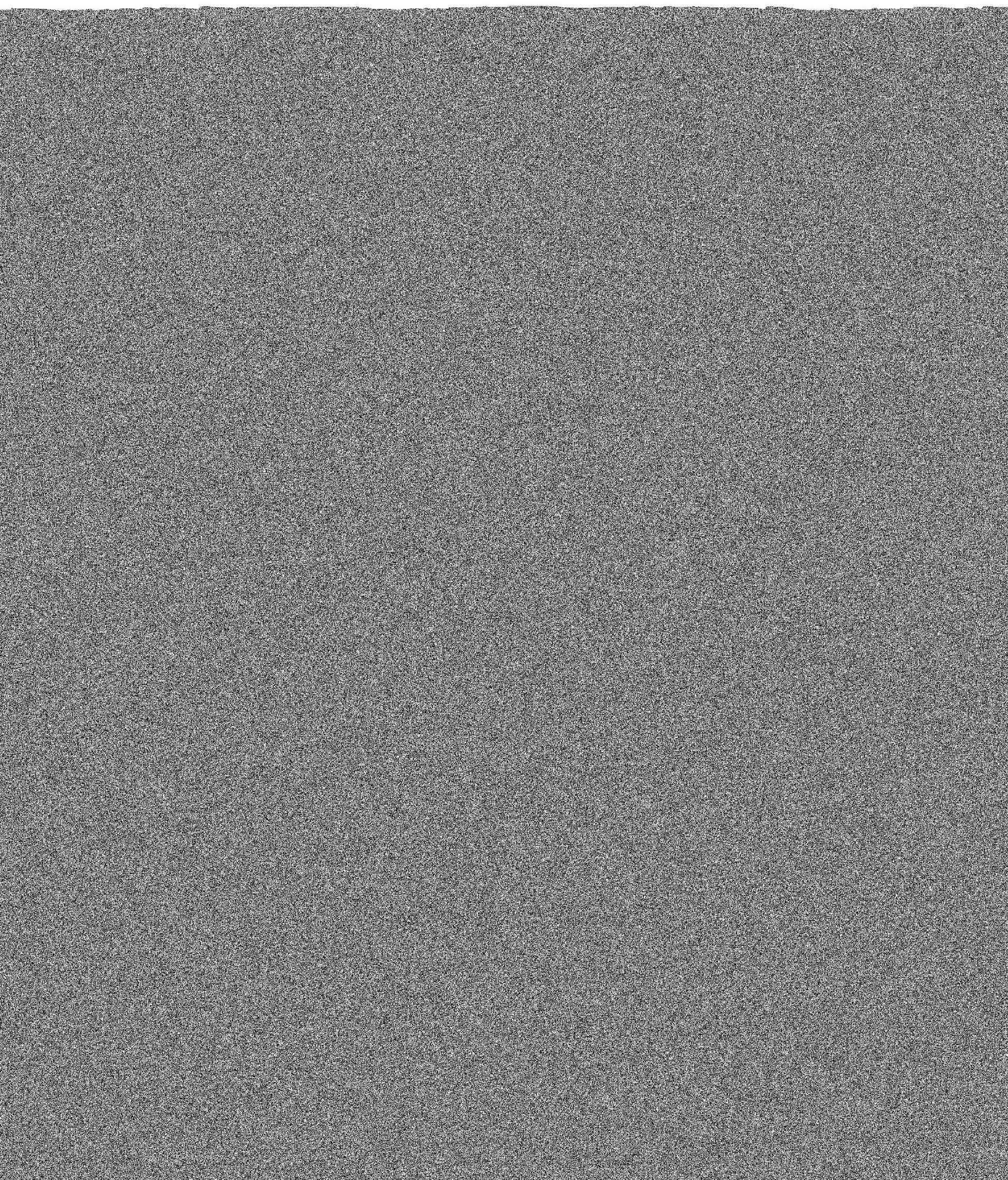


vida y de su obra: «Esto es notorio en el caso de san Agustín, que representa evidentemente un brote inesperado de modernidad en las postrimerías del mundo antiguo. San Agustín va a anticipar el gran descubrimiento románico que consiste en hacer coincidir el personaje que se supone hablar con el efectivo hombre que escribe. San Agustín habla desde su yo, y por eso fue un escándalo sin par en el mundo antiguo. No sólo escribe sus confesiones - género literario en el que el punto de 'hablada' coincide exactamente con la criatura real que escribe-, sino que toda su obra es, en efecto, confesión, como la de Chateaubriand. Por eso suena a grito. El estilo de san Agustín es un grito pelado, aunque bastante retorcido» (IV, 389, 1932).

San Agustín, para Ortega, se adelanta a la modernidad, como quedó dicho. En él coincide realmente el personaje con el hombre. Así deja de ser un mero ventrílocuo de lo divino o del hado; también se abandona en san Agustín el sentido gremial de la vida que habla en nombre de todos y produce un 'nosotros' abstracto que no se sabe muy bien a quién se refiere, pues el mismo gremio no sabe a qué atenerse y qué responsabilidad le compromete en ese genérico colectivo y anónimo 'nosotros' del hombre medieval impersonal y sin rostro.

Al hablar, san Agustín desde su yo produce, según Ortega, un escándalo sin par en el mundo antiguo. Crea así el hombre interior y la auténtica personalidad que antes no existía propiamente en el mundo antiguo (profesor Pinillos). No sólo las Confesiones poseen ese carácter personalizador, íntimo e intimidante, directo e interpelador, sino que toda su obra se dirige al corazón del hombre porque brota, a su vez, de ese mismo corazón: un abismo llama a otro abismo en el misterio del hombre. Ciertamente el mensaje agustiniano es un grito máximo por la resurrección en la catástrofe y la decadencia máxima de Occidente: La caída de Roma y la aparición salvaje de los nuevos pueblos.

Añade Ortega que el grito de san Agustín es pelado y retorcido, se trata de una experiencia dramática, es difícil remontar la catástrofe que ha inundado todo el mundo occidental. San Agustín asume personalmente esta crisis que le retuerce el corazón: la angustia le rodea por todas partes. Agustín vive él mismo la crisis de valores del imperio occidental, duda él mismo, no hace una comedia de la duda, la duda le retuerce. Su obra es la declaración de un corazón angustiado que se siente muy limitado ante Dios para enfrentar la catástrofe de su mundo y resolverla, el grito dado con todo el poder expresivo de un corazón absolutamente sincero ante el naufragio de la civilización romana que, al fin y al cabo, le había hecho profesor del Imperio. También alude, sin duda, Ortega - al hablar del grito pelado y un tanto retorcido de san Agustín- a los que todavía le usaban para recaer en el tenebrismo romántico y alejar la claridad nueva, colocándose de espaldas a la luz, que es, ciertamente, justo lo contrario de lo que hizo Agustín. 
5. San Agustín, la crisis de fondo y el hombre interior

Según Ortega, el hombre moderno que atraviesa por una profunda crisis necesita recurrir de verdad a los hombres fundamentales de la historia, a los grandes guías de la humanidad. Éste debe ser el sentido de los centenarios y, en concreto, el verdadero objetivo de un centenario de san Agustín. Pero, con frecuencia, la celebración se queda en meros juegos florales. Dice Ortega así: «En las fiestas del centenario el rico heredero repasa complacido el tesoro que los siglos han ido destilando. Pero es triste, depresivo, repasar un tesoro de monedas depreciadas. No sirve tal ocupación para otra cosa que confirmarnos la insuficiencia de lo clásico. A la luz cruda, exigente, inexorable, de la presente urgencia vital la figura del clásico se descompone en meras frases y aspavientos. En estos últimos meses hemos celebrado los centenarios de dos gigantes —san Agustín, Hegel- y el resultado ha sido deplorable. Ni sobre uno ni sobre otro se ha podido publicar, con tal motivo, una sola página nutritiva y alentadora» (IV, 397, 1932).

Según Ortega, ya en su tiempo, hay una crisis total, también del clasicismo y la herencia europea; el recuerdo de los grandes gigantes de la humanidad se reduce a una retahíla de admiraciones sin provecho para nuestra triste vida inmediata. En realidad la mayoría de los centenarios los celebran los que no los necesitan y por eso se reducen a pura anécdota. Sería necesario ir al fondo de esos grandes hombres y su obra - como hace Ortega con Goethe- para que celebrar centenarios deje de ser un conjunto de vanos divertimientos inútiles. Así ha ocurrido, según Ortega, con los centenarios de san Agustín y Hegel, en su tiempo, porque no se ha querido ir al fondo del hombre que es donde está el problema, como dice muy bien Ortega: «Lo problemático es el fondo, nuestro fondo» (IV, 425, 1932).

Es necesario tomar la cuestión desde sus orígenes tal como la plantea Ortega. Ahora, la nueva frontera en Europa es la libertad. Todos los grandes hombres nos gritan ' $¡$ Libertad!' (IV, 424). Y lo que nos señalan, a lo que nos invitan es a la Liberación: «la liberación hacia sí mismo» (IV, 425). Hay que ser hombres auténticos, que eso es ser un héroe, ser realmente uno mismo, 'ser sí mismo'; pero nosotros no sabemos bien lo que es uno mismo. Lo decía Plotino: ¿Nosotros? ¿Quién somos nosotros? Es difícil encontrarnos a nosotros mismos, descubrir nuestro hombre auténtico, revelar nuestra verdadera personalidad: «Lo buscamos en torno y no lo hallamos. Penetramos en nuestro interior seguros de encontrarlo. In interiore homini habitat veritas había dicho san Agustín. Nos imaginamos nuestro interior como un recinto, una cámara hermética y limitada donde no puede perderse nuestro yo, escabullirse, fugarse. Allí no habrá escape: podemos echarle a nuestro Yo la mano al cuello, como hace el policía con el ladrón acorralado. $Y$, en efecto, nuestra intimidad tiene sus cuatro paredes bastante definidas. Lo problemático es el fondo, 
nuestro fondo. Nos preguntamos: ¿creo yo en el fondo eso que parezco creyendo en política, en arte, en ciencia, en amor? Porque el 'mí mismo' consistirá en lo que yo sea en el fondo» (IV, 425, 1932).

Es así como el hombre se convierte en buzo de sus propias y, sin embargo, oceánicas profundidades, un minero de humanidad como dirá, en otro lugar, Ortega. San Agustín nos anima especialmente a avanzar hacia la gran profundidad 5 , a transcendernos hasta el abismo de Dios al que el hombre invoca, al fin, desde el abismo de su misterio y enigma. Mientras tanto, el hombre, como un arqueólogo infatigable, va descubriendo capas y capas de su vida sin encontrar, tan fácilmente como en su principio parecía, tierra firme y definitiva en su continente. Por eso van los hombres a admirar el mundo y se olvidan de sí mismos, eso es más fácil... El hombre camina con temor y temblor hacia su fondo insobornable, hacia su gran profundidad: «Nuestro fondo es mucho más abismático de lo que suponíamos» (IV, 426).

El hombre tiene que inventarse a sí mismo, - pues se ha hecho cuestión de sí mismo; quaestio mihi factus sum, decía san Agustín-, descubrirse y hacerse a sí mismo como un pequeño Dios, como un Dios de ocasión que decía Leibniz, frente a la circunstancia que le solicita y desde el misterio que Dios ha puesto en él. Sólo así puede realizar lo mejor de lo mejor de sí mismo, su auténtica identidad, su personal, única e intransferible vocación, misión y destino.

Con frecuencia el hombre se pierde en las cosas, no se libera de ellas y entonces se hace una vida falsa, se chantajea a sí mismo, en su más íntima personalidad, en su auténtico yo; y así falsifica su vida, se convierte en un suicida en pie, pues ha matado el hombre más auténtico que dentro de sí tenía y no deja ver la luz. Así que el aborto bien entendido comienza por uno mismo. Ortega, como veremos, vuelve sobre este tema de la falsificación de la propia vida con una fuerza tremenda. Decía Nietzsche que nunca acabamos de quitarnos nuestras máscaras; sólo si nos conocemos como Dios nos conoce hasta el fondo abismático de nuestro misterio, nos realizaremos de verdad con autenticidad, en otro caso a cada uno se nos aplica el terrible larvatus prodeo que decía Ortega: avanzamos enmascarados. Pero ahora es aún más terrible porque no son ya los demás los que nos enmascaran sino que cada cual se hace máscara de sí mismo. Y a esto se juega constantemente en nuestro siglo. Volvamos, pues, con san Agustín, al hombre interior, al hombre auténtico, no nos falsifiquemos más a nosotros mismos, no nos engañemos más y preguntémonos con Agustín: ¿Qué hemos hecho de nosotros mismos? Tal es el drama y la crisis de fondo de nuestro tiempo.

5. Ciolini, C., Cristo Maestro interior y camino hacia el Padre, en La Búsqueda de Dios, Publicaciones Agustinianas, Roma 1981, 153. 


\section{San Agustín, Luis Vives, la crisis de Europa y el cristianismo}

Nos refiere Ortega que el humanista Luis Vives representa un momento clave de la crisis general y profunda en las creencias fundamentales de Europa. Está cambiando la forma anterior de vivir la fe y se inventan nuevos modos de ser cristiano. Ortega hace esta descripción como símbolo de un problema que afecta decisivamente a muchas personas, en sus creencias, incluido Ortega mismo. Ante esta situación que recuerda Ortega el hombre actual se hace juntamente con él una serie de preguntas importantes no fáciles de contestar. Dice Ortega así: «Vives es cristiano, pero era erasmista. ¿Es cristiano un erasmista? Un erasmista es cristiano? Desde luego no lo es como lo era santo Tomás de Aquino, ni como lo fue san Agustín, ni siquiera como lo va a ser Ignacio de Loyola» (IX, 524, 1940). Y Ortega exclama: «¡Ha habido tantas maneras profundamente distintas de ser cristiano, es decir, de creer en el Dios de la Biblia y del Dogma!» (IX, 523-524, 1940).

El cristianismo moderno, por lo regular, es más activo incluso en personajes tan contrapuestos como san Ignacio y Lutero. En Vives rebrota la fe 'con nueva forma', pues el pasado como tal no vuelve nunca. «Porque es bien seguro que Ignacio de Loyola, en quien se reafirma la fe tradicional, no es cristiano como san Agustín, no cree en Dios en la misma forma precisa en que creía san Agustín. Ni lo creído por él, Dios, es para él exactamente lo mismo que para san Agustín, ni su creer posee los mismos quilates y la misma contextura. Es irremediable que así sea. Todo en el hombre es histórico y, por tanto, siempre diferente: hoy es otro que ayer, y el ayer no retorna, no retorna jamás... El hombre va siendo, a lo largo del tiempo, estoico, cristiano como san Agustín, cristiano como santo Tomás, más tarde como san Francisco, y aún más tarde como Erasmo y Vives, o, lejos de ellos, como san Ignacio; y luego deja de ser cristiano y es racionalista, y hoy es voluntarista; y va siendo el hombre todo eso y lo va des-siendo - sustancial peregrino del ser- sin poder quedar nunca fijo y para siempre en un modo de ser quieto y definitivo; sustituyéndose siempre a sí mismo, inventando un mundo donde alojarse y destruyéndolo después para crear otro, perpetuo emigrante de mundo en mundo, de creencia en creencia, de ilusión en ilusión...» (IX, 524-525, 1940).

Ortega se ve en Vives y ve que Vives tampoco se ha logrado del todo, ni ha conseguido esa fe en plenitud que respondiera realmente al desafío del nuevo mundo moderno. Pero Vives no fue ateo, porque ateos en aquella época, nos dice Ortega, sólo se declaraban los botarates. Ortega tampoco fue ateo ni antirreligioso. Por eso, como ha dicho Miguel de la Pinta Llorente, en su excelente tratado sobre el proceso de Luis Vives, no hay que ser inquisitoriales. Vives fue un hombre religioso, honrado patriota, y eso es bastante. $Y$ tenemos suficientes datos, hoy, para afirmar que Ortega también lo fue. No hay que confundir la escolástica con el cristianismo. En tiempo de Vives el hombre ac- 
túa desde sí mismo, no desde Dios como el medieval; por eso Vives ya no es tanto teólogo como filósofo y praesertim Anthropologo (IX, 529). Es decir, que la razón radical del ser de su vida habrá de ser el hombre y en él tendrá que presentarse hasta el mismo Dios si se digna revelarse. Para el medieval, toda concepción antropocéntrica era pecado: «No se olvide la taxativa definición del pecado dada por san Agustín y que aún tiene plena vigencia sobre las almas en tiempo de Dante y aun posterior. Pecado - dice san Agustín- es todo aquello que el hombre hace tomándose a sí mismo como principio. Es decir, que afirmarse el hombre a sí mismo, que todo entusiasmo hacia algo humano y de este mundo es ya pecado; es lo que san Agustín llamaba 'concupiscencia'» (IX, 528, 1940).

Dicho llanamente, para el medieval el pecado es el hombre. Porque el medieval tiene una concepción teocéntrica, como el antiguo la tiene cosmocéntrica y el moderno antropocéntrica (IX, 528). Para éste, el hombre no sólo no es pecado sino que, como para los Padres de la Iglesia, la gloria de Dios es el hombre viviente, según decía san Ireneo. Sólo se le pide al hombre que reconozca que Dios debe ser, a su vez, la gloria del hombre. Nada más y nada menos.

Como consecuencia, la fe y la moral cristiana dejan de ser una carga de obligaciones y se transforman en confianza y amistad, esperanza y seguridad en Dios para bien del hombre. Ortega trata este sentido de la fe como confian$z a$, en san Agustín, cuando habla de la formación prístina de los pueblos. Al hablar de la fe que los pueblos desarrollan en los momentos de peligro hacia su autoridad más valiosa - que como Ortega advierte, de paso, no hay que confundir con el origen neurótico del Estado hitleriano-, Ortega dice que en estos casos la fe se entiende más bien como confianza y esperanza. Añade Ortega, entonces, que así entiende la fe san Agustín y que esa es la verdadera fe puesto que la mera creencia en que Dios existe la tienen muchos hombres y no por eso son religiosos. El mismo san Agustín decía que también los demonios saben que Dios existe pero que no confían en él y de nada les aprovecha. Ortega lo expone así: «Porque esto es la fe cuando se dirige a un ser personal: confianza, esperanza. Esto es también la fe en Dios y no como ordinariamente creen los totalmente remotos de la Teología, que creer en Dios es simplemente creer en que existe, en que lo hay. Muchos hombres creen que Dios existe y, sin embargo, no son religiosos ni tienen fe en Dios. La creencia o fe en Dios, más aún, y no es paradoja, que creer en que existe es confiar en Él y tener en Él esperanza; es la diferencia que ya troquelaba san Agustín cuando distinguía entre creer que hay Dios y creer a Dios. $Y$ es muy posible que la única manera que tiene el hombre para poder creer de verdad en que Dios existe es, antes de creer esto, creerle a Él, confiar en Él aun, todavía para uno, inexistente. Esta extraña combinación es la auténtica fe. Yo no sé si con lo que he dicho (me es- 
cucha, creo, algún teólogo) he dicho alguna herejía, pero de lo que estoy cierto es que es la idea más eficaz que cabe tener de la fe en Dios» (IX, 104, 19481949).

Pero ese Dios de la fe, que por un lado es fascinante y seductor por otro nos pone ante nuestro mal, nos acusa y enfrenta con nosotros mismos. Y san Agustín describe esta situación del hombre perfectamente: «Con su enérgico y torsionado decir, san Agustín clama ante Dios al sentirse en su presencia: $E t$ inhorresco et inardesco. 'Me espantas y me exaltas'; 'me horrorizas y me hechizas'» (IX, 126, 1948-1949). Esta doble faz de lo divino hace que unos hombres se sientan ante la religión felices y otros se sientan amedrentados, que unos hombres religiosos parezcan acoquinados en su fe y otros se encuentran gozosos, libres y creadores en ella, a pesar del esfuerzo que lleva consigo mantenerse, a la vez, como creyente y auténticamente humano. San Agustín fue uno de esos hombres que estuvo siempre abierto al pensamiento y a la filosofía, a los valores positivos del mundo pagano y a la vez mantuvo su creencia bien alimentada de valores humanos colmados, de ahí su actualidad, hoy, para nosotros que nos encontramos también en la tentación de elegir entre una cosa $u$ otra en un mundo que nos ofrece a la vez tantas cosas buenas y malas y nos atrae con tan diversas, excelentes y falaces, culturas. En efecto, dice Ortega: «san Agustín es el gran ejemplo de un alma sometida sucesivamente a la gravitación hacia heterogéneos centros de atracción. Esto da a su fe el carácter de una nueva adquisición, insuficientemente consolidada, que el individuo necesita reanimar de continuo con su voluntad de creer. La teología cristiana ha entendido siempre por fe esta convicción precaria, sin duda más meritoria, pero más parecida a lo que he llamado adhesión a ideas verdaderas que a una creencia» (IX, 334). Esta vivencia agustiniana de la fe en Dios impide que esa fe sea una fe vaga y la obliga a un esfuerzo constante para ganarse la vida y la supervivencia propia con el sudor de su frente; así no puede vivir de prestado, sino que tiene que alimentarse día a día con la oración, el estudio y el trabajo, porque necesita crearse una cultura que es cultivo y vivencia renovada sin cesar de eso que dice creer. Así entendía Vives la cultura y no es por casualidad que este autor da a la imprenta en 1521 sus famosos Comentarios a la Ciudad de Dios de san Agustín (IX, 508, 1940).

\section{San Agustín, el cristianismo y la escolástica, la vida de fe y la cultura}

Ortega nos introduce en un determinado momento de su obra en el problema de las relaciones entre la cultura griega y el cristianismo. Según Ortega, como el cristianismo, al principio, no era suficientemente fuerte para dar en serio la batalla al mundo griego, tuvo que integrar la fe con la ciencia aristotélica. Así: «Alberto Magno y santo Tomás adaptaron el cristianismo a la ideología griega. Es la segunda helenización del espíritu cristiano: la otra, si se 
cuenta hasta san Agustín, tuvo lugar en su misma cuna. Nace en medio de la cultura grecorromana y no tiene más remedio que filtrar hasta su médula elementos extraños. No es fácil imaginar dos inspiraciones más antagónicas que la cristiana y la griega» $(\mathrm{V}, 91,1933)$.

El cristianismo no se identifica con una sola cultura pero tiene que pactar, hasta cierto punto, con cada una si quiere transmitir, sin violencia, la fe. Así lo hacen los grandes escolásticos y también lo hace, a su modo, san Agustín. Pero el espíritu griego y el cristiano son enormemente dispares. El Logos griego no es ni mucho menos el Logos cristiano. San Agustín adopta, por ejemplo, el platonismo, muy a su manera, según la Biblia cristiana. En cierto sentido se puede decir que el griego es ciego para el trasmundo al menos tanto como lo es el cristiano para la Naturaleza. Ortega recuerda que Jean Guitton ha escrito un libro con el título: El tiempo y la eternidad en Plotino y san Agustín, donde se advierte de esa gran diferencia. Allí, las relaciones entre el griego y el cristiano, nos dice Ortega, se parecen al diálogo en el que un ciego pregunta al tullido: ¿cómo anda usted, buen hombre? A lo que el tullido responde: ;Como usted ve, amigo! $(\mathrm{V}, 91,1933)$.

Ésta ha sido para Ortega la gran tragedia para el cristianismo. Santo Tomás y san Alberto, según Ortega, no habrían tenido más remedio que imponer al espíritu evangélico-cristiano, la tiranía de la 'deformación aristotélica' arrojada por Averroes y Avicena sobre Occidente con el Corpus Aristotélico. A eso llamó Gilson, dice Ortega, la filosofía cristiana. Según Ortega eso era un aplastamiento y un acto más en la tragedia del cristianismo. Para Ortega: «La auténtica filosofía cristiana sería una línea irreal que sólo podemos fijar en algunos de sus puntos: san Agustín, los Victorinos, Duns Scoto, Eckhart, Nicolás Cusano» $(\mathrm{V}, 92)$.

Como se ve, Ortega se opone muy claramente a una determinada escolástica y se adscribe a una línea agustiniana del cristianismo que no se contenta con una seguridad naturalista. No obstante Ortega no va a ser duro con Gilson que dice le ha enseñado mucho. Por nuestra cuenta diremos que Ortega podría haber conocido a Gilson en casa del especialista francés, en san Juan de la Cruz, Jean Baruzi según consta en la correspondencia de éste con Ortega en la que le invita a su casa y le dice que podrá encontrar allí a Marcel y Gilson entre otros.

Según Ortega, el cristianismo aparece como una vida que supera la cultura de la desesperación reinante en Grecia y Roma a la llegada del cristianismo. Ya vimos que Cicerón desesperaba de poder alcanzar alguna verdad, ni siquiera en religión. San Agustín mismo pasó dramáticamente por esa experiencia del escepticismo. Muchos desesperados del mundo y de la sociedad, corrompida y deshumanizada, encontraron en el cristianismo la nueva tabla de salvación y el nuevo camino de la vida. Ésa es la razón, según la teoría de E. Meyer, 
utilizada por Ortega, por la que las masas acudieron constantemente al cristianismo y a las asambleas cristianas.

Pero, poco a poco, el hombre vuelve a creerse, de nuevo, él mismo, Mesías y Salvador, y ése es el error y el pecado original del hombre según san Agustín. Lo dice así Ortega: «La perspectiva en que solemos movernos nos hace creer que el hombre con la naturaleza en torno se basta para que su vida sea algo positivo. Éste es el error radical de que hay que curarse - la definición misma del pecado que da san Agustín en la Ciudad de Dios; sibi quodam modo fieri atque esse principium: creer que es principio de su ser, y de su hacer; en suma, hacerse ilusiones respecto a sí. Para el cristiano, el hombre confiado en sí, que aún espera algo de sí, es el esencial pecador» $(\mathrm{V}, 119,1933)$. Por eso la soberbia, el creerse inocente es el origen de todos los pecados: $C a$ put omnium peccatorum superbia est, dice san Agustín» (IX, 467). En otros casos a esa fuente del pecado se llamará concupiscencia: «Para el cristianismo, desde san Agustín, la fuente del pecado es la concupiscencia» (VII, 509, 1950). Ésta estimula al pecado e intoxica la mente humana (VII, 491, 1950); cfr. De Civitate Dei, VI, 11; 16).

Para el cristianismo, es la relación con Dios la que hace realmente al hombre, no su autosuficiencia. «De aquí el desdén de los primeros siglos cristianos a todas las ocupaciones mundanales: a la política, a la economía y a las ciencias. Lo único verdaderamente real es el alma y Dios. El alma es el nombre tradicional con que se designa el yo. San Agustín, prototipo del hombre hecho ya cristiano, del convertido, dirá: 'Deum et animan scire cupio. Nihilne plus? Nihil omnino' $(\mathrm{V}, 126,1933)$. No obstante, como bien ha observado el filósofo de la ciencia Thomas Kuhn ${ }^{6}$, en el monacato agustiniano se da un cierto cultivo de las ciencias y un valor nuevo a los estudios, aunque al servicio de la fe cristiana. No hay incompatibilidad entre ser clérigo o monje y ser hombre de ciencia; todo lo contrario, es una exigencia de la fe conocer la obra de Dios en el mụndo por el estudio. San Agustín mismo inició una auténtica filosofía cristiana. Y Ortega lo vio así: «San Agustín, genialmente, intenta descubrir conceptos nuevos, adecuados a la nueva realidad, y, sin excesivo error, puede decirse que cuanto hay de efectiva filosofía cristiana se debe a él. Pero no bastaba un hombre, por genial que fuera: era menester des-pensar todos los viejos conceptos, liberarse de ellos y forjar toda una ideología radicalmente original. La masa enorme y sutilísima de la ideología griega, gravitando sobre estas horas germinales del pensamiento cristiano, lo aplastó» $(\mathrm{V}, 126,1933)$.

Según Ortega, Platón sedujo hacia su ideología 'archimundanal' a muchos cristianos que pasaron a pensar como los griegos 'con los ojos y las ma-

6. KUHN, Th., La révolution copernicienne, Fayard, Paris 1973, 123. Trad. del inglés P.A. Hayli. Esto no quiere decir que san Agustín fuera un científico. 
nos'. Era el sensualismo. Como el mismo Platón hablaba de otro mundo, aparentemente se parecía a los cristianos. «El propio Agustín reconocía en el platonismo la mejor introducción a la fe cristiana. Mas sin que yo pueda detenerme ahora a mostrarlo, forzoso es decir, que se trataba de un quid pro quo. El platonismo no es en ningún sentido cristianismo» (V, 127, 1933).

Dios es otra cosa; no puede quedarse el cristianismo en un platonismo para el pueblo, como criticaba Nietzsche. Éste no es el sentido ni el conocimiento cristiano de las cosas sino un engaño dramático de toda la civilización occidental al dejarse fuera la mitad del ser humano bajo la capa de espiritualizar. También, en ese sentido, es san Agustín padre de Occidente. Él lo ha sacado del conocimiento oficial y opresor, dominante en esa sociedad, y lo ha conducido al verdadero conocimiento y a la verdadera realidad, a la patria de todos, la que nos enseña la fe, única comprensión verdadera del mundo y de la vida. «Más aún: Para este puro cristiano que es san Agustín, alma tórrida de africano, no hay más conocimiento que ése» $(\mathrm{V}, 127,1933)$. Bien dijo Max Scheler que para san Agustín no conocemos a Dios a la luz del mundo, sino que conocemos el mundo a la luz de Dios ? . Para entender hay que creer, es Dios quien nos enseña la verdad: «San Agustín vive entre el siglo IV y el v. Si ahora nos trasladamos seis siglos avante, nos encontramos la vida cristiana un poco modificada en su estructura. El lema agustiniano era éste: Credo ut intelligam - para conocer es preciso antes creer-; por tanto, no hay, en rigor, conocimiento como algo aparte y por sí. Conocer es, en su raíz, recibir revelaciones e iluminaciones- por consiguiente, creer. Dios es lo único que verdaderamente hay. El hombre considerado por sí, no tiene realidad» $(\mathrm{V}, 128,1933)$.

Luego viene la segunda parte: es el hombre quien tiene que entender, recibir esa verdad. Entonces, por muy exclusiva que quiera ser la 'tesis agustiniana', el hombre también debe colaborar con Dios. «San Agustín, en su fervor extremista, se preocupaba sólo del origen, al fin y al cabo divino de la verdad, y desatendía ese estadio del conocimiento en que el hombre no se limita a creer por cuenta de Dios, sino que discurre, entiende, razona inevitablemente por cuenta propia. Desatender eso, preocuparse sólo de Dios radicalmente era la estructura de la vida cristiana en la primera escena» $(\mathrm{V}, 128,1933)$.

Poco a poco es preciso entenderse con las realidades concretas. El hombre, aunque sea poco, tiene que intervenir, y así deja de ser nada sin más. Esto es ya san Anselmo. «Frente al lema de san Agustín: Credo ut intelligam, el de san Anselmo suena así: Fides quaerens intellectum» (V, 129, 1933). La fe también necesita la inteligencia; no puede vivir como una fe vaga o distraída. Fi-

7. Scheler, M., Vom Ewigen im Menschen, Francke, Bern ${ }^{4}$ 1954, 194: Piensa san Agustín «dass wir also Gott als Geist nicht in lumine mundi, sonder umgekehrt die Welt in lumine Dei erkennen". 
nalmente, santo Tomás reconoce por completo a la razón, cosa que a los primeros creyentes les parecería escandaloso. Pero las Iglesias, además de hombres fervorosos, necesitan administradores y no es difícil que se caiga en la tentación de preferir excesivamente a éstos sobre aquéllos. Por eso dice en otro lugar, que veremos, Ortega: la Iglesia prefirió a santo Tomás. Aparte que, como todo el mundo sabe, aunque no siempre se reconoce: «santo Tomás fue un tremendo humanista» $(\mathrm{V}, 130,1933)$.

Más tarde y también paso a paso, la fe se convertirá principalmente en emoción y moral, imitación y devoción ejemplar de Cristo, conducta concreta con desinterés del dogma, del ser divino, sus atributos y misterios. «Eso es lo que ha preocupado desde san Agustín hasta el siglo XIV» (V, 147, 1933). A partir de aquí se desprecia la sabiduría y se vive de la simplicidad. Los 'frailes' no se ocupan ya realmente de lo 'divino'. Todo se viene a tierra en este sentido. El hombre de la devotio moderna, al ocuparse de Dios, solamente se ocupa de 'sí mismo'. Y Ortega sentencia: «Habría sido para escuchado lo que san Agustín hubiera dicho ante esta devotio moderna, él que era una especie de fiera de Dios. Lo más suave habría sido esto: 'Eso es más una moral que una fe'» $(\mathrm{V}, 149,1933)$.

Nueva gran lección de san Agustín para nuestros días: El cristianismo postmoderno ha dejado también, al parecer, la moral - la fe ya hacía tiempo que no le interesaba nada - y se queda solo y sólo con «los estados espirituales y aun corporales de sí mismo mientras se ocupa de Dios» (V, 149, 1933). Las emociones mandan y es hora de barrer. Molinet, un cronista más bien piadoso del tiempo de la devotio nos trasmite estos versos nada halagüeños:

Prions Dieu que les Jacobins/Puissent manger les Augustins

Et les Carmes soint pendus/Des cordes des Frères Mineurs.

$$
\text { (V, 149, 1933). }
$$

No obstante, Ortega sabe distinguir perfectamente y admite que ha habido y hay diversas formas de ser cristiano y que sería puro equívoco identificar unas cosas con otras. "Como es parejamente entregarse al equívoco llamar religión a lo que el romano de la primera guerra púnica creía, sentía y hacía en relación con sus dioses, y al Cristianismo, o aun dentro del Cristianismo no advertir la heterogeneidad radical entre el Cristianismo de san Agustín y el de Newman» $(V, 540,1941)$.

Según Ortega, el catolicismo representa, frente al protestantismo, una viva conciencia histórica en la religión a pesar de la dimensión eterna de ésta. Y por consiguiente el catolicismo comprende también mucho mejor la debilidad humana. Sólo el catolicismo optimista pudo hacer el derroche de religiosidad y folklore o espíritu popular que tanto admiraba Nietzsche cuando criticaba la miopía del protestantismo al respecto. En este sentido también sabemos de la gran humanidad de Agustín como pastor con sus fieles de Hipona. En efecto, 
el verdadero cristianismo es lo eterno temporalizado, Dios hecho hombre, Dios en el hombre, lo divino en lo humano, lo eterno en la historia. Al fin y al cabo, todo esto hace aún más verdadero el catolicismo por su derroche de humanidad y porque recoge también mejor el sentido de Dios como supremo Hacedor. El hombre toma ejemplo de este Dios activo, sobre todo en la modernidad. Por eso cuando Ortega vaya a decirnos que el hombre no tiene naturaleza sino que tiene historia, enseguida nos dirá que también en Dios es así como lo afirma san Agustín. Veamos el famoso texto orteguiano: «En suma, que el hombre no tiene naturaleza, sino que tiene... historia. $\mathrm{O}$, lo que es igual: lo que la naturaleza es a las cosas, es la historia - como res gestae- al hombre. Una vez más tropezamos con la posible aplicación de conceptos teológicos a la realidad humana. Deus cui hoc est natura quod fecerit..., dice san Agustín*. Tampoco el hombre tiene 'otra' naturaleza que lo que ha hecho (VI, 41, 1935). También nosotros decimos, aún hoy, que cada uno es hijo de sus obras. Pues con su hacer se hace y se des-hace.

\section{San Agustín y el problema de la filosofía cristiana}

Ahora bien, en ese acercamiento del catolicismo a la realidad y a la historia, del que acabamos de hablar, no todo ha sido positivo. A veces se han establecido contubernios lamentables y vergonzosos. Otras se ha caído en manos de un determinado tipo de pensamiento de un modo unilateral. Por supuesto, cada uno aduce excelentes razones para justificar lo que ha hecho. Así Gilson nos explica que los que siguieron a Aristóteles tomaron el camino más difícil; en cambio los que siguieron a Platón cogieron el más fácil. Pero Ortega no está de acuerdo con esto y le duele que las cerrazones mentales de unos y de otros, incluidos los ockamistas, pues todos se proponen como la verdadera filosofía cristiana, han producido un daño enorme, y así, según Ortega, «lo que hubiera sido la auténtica y original filosofía cristiana ha quedado nonato, $y$ con ello ha perdido la Humanidad una de sus más altas posibilidades» (VIII, 167, 1947).

La razón por la cual Ortega no está de acuerdo con Gilson es porque el $l u$ men naturale es en Suárez y en santo Tomás un hecho último y por tanto algo irracional mientras constituye «para san Agustín un problema tremendo, que se ve obligado, como es debido, a enuclear, constituyendo con motivo de él toda una admirable teoría: el 'iluminismo'. Luego dirá Gilson que santo Tomás tomó el camino más difícil y san Agustín el más fácil. San Agustín fue mucho más filósofo que santo Tomás, como se manifiesta en su resuelto embestir a los problemas últimos. Pero no fue, ni podía ser en su tiempo, un insuperable

* De Genesi ad litteram, VI, 13,24; PL 24. 
administrador de la herencia filosófica greco-arábiga - gótica, que es lo que fue santo Tomás. En este sentido sí es comprensible que la Iglesia - no el catolicismo - haya preferido a santo Tomás, porque la Iglesia es un Estado, y los Estados han preferido siempre, con cierta razón, los buenos administradores a los genios. Los genios son siempre perturbadores y peligrosos. Toda creación es por su reverso un cataclismo. Prueba de ello la primera creación: la de los ángeles. ¡Buena se armó!» (VIII, 180, nota 1, 1947).

Como se ve, Ortega prefiere la genialidad de san Agustín al administrador fiel que es santo Tomás. No obstante la razón que da de la genialidad: el lumen naturale en san Agustín, parece que no la había percibido del todo hasta su obra sobre Leibniz en 1947. Pues pocos años antes, todavía en Lisboa, dice lo siguiente: El hecho absoluto y misterioso de que en el mundo exista sentido, nous, no es fácil de explicar. «Es la cuestión tremenda de lo que Cicerón, tomándolo de los estoicos, llama lumen naturale, idea que por él fue trasmitida y que recibió ya de él y de los neoplatónicos, san Agustín. Pero ni los estoicos, ni menos, claro está, Cicerón, ni los neoplatónicos, ni san Agustín, se ocupan en hacernos ver en qué consiste y se limitan - por ejemplo este último- a decir que nos viene de Dios, por el hábito muy respetable, pero muy cómodo, de descargar sobre el hombro de Dios todas las cargas incomprensibles que sobre el hombre caen. Pero dejemos ahora este abismático problema» (XII, 281, 1944). Quizá, por las últimas palabras, podemos deducir que Ortega pensaba volver sobre este asunto más a fondo, como lo hace efectivamente en 1947 , en su gran obra sobre Leibniz, donde hay también unos ataques muy definitivos a la ontología griega y en consonancia con ella a la escolástica.

Además explica Ortega que se prefiere a los sistemáticos o filósofos gramáticos porque, en realidad, no interesa propiamente filosofar sino tener una terminología para la teología que es a lo que se reduce, según Ortega, la filosofía en muchos seminarios (VIII, 180-181, nota 1). Se prefiere así un Dios lógico y sin paradojas y por tanto, sin problemas, en teología. Pero el verdadero Dios, como la verdadera teología, no es así; como lo dijo muy bien R. Otto, con palabras agustinianas, Dios es «mysterium fascinans y mysterium tremendum» (VIII, 212, 1947). Ya lo había señalado el genial obispo de Hipona: «Refiriéndose a Dios dice san Agustín: Et inhorresco et inardesco. Inhorresco, in quantum dissimilis ei sum. Inardesco in quantum similis ei sum». Confesiones, II, 9,1. Otto lo cita en apoyo de su doctrina» (VIII, 212, nota 2, 1947). Llama la atención la insistencia de Ortega en citar este texto en el que se apoya R. Otto para describir lo santo. Dice Ortega así en otro lugar: El misterio es tremendo y fascinante, «horrorizar y fascinar son lo característico de lo santo en su verdadera acepción. Al aplicarse en los últimos siglos la palabra santo a ciertos hombres virtuosos que la Iglesia ha canonizado, perdió el voca- 
blo el esplendor ultraterrestre y terrorífico que tiene en la lengua latina y que pervive en las formulas de la Iglesia misma, como en la antífona que dice a Dios: Tu solus Sanctus, tu solus Altissimus, o como san Agustín expresaba su sentir cuando se acercaba a Dios: Et inhorresco et inardesco - me horrorizas y me hechizas, me espantas y me entusiasmas» (XII, 256-257, 1944).

Así es Dios, así es el hombre también de tremendo y enigmático, pero es más fácil levantar un monumento al principio de no-contradicción y enseñar que la vida no tiene realmente contradicciones. Pero el tiempo - que es el más sabio de todos - se encarga de despertar un buen día, a los más seguros, de la evidencia per se nota. Mientras tanto, según S. Vicente de Lerins, hay que procurar que todos crean lo mismo: "'magnopere curandum est, ut id teneatur quod semper, quod ubique, quod ab omnibus creditum est'. Lanza esta fórmula precisamente contra las intervenciones de san Agustín, a quien en efecto para Padre de la Iglesia le sobraba su mucho de filósofo» (VIII, 255$256,1947)$. Se ve que no todos creen fácilmente lo que siempre, por todos y en todas partes fue creído; lo que no deja de ser un problema lógico muy parecido a la paradoja de Grelling. Al parecer, la mayoría no cree lo que cree la mayoría.

Parece ser que el Dios lógico de los hombres no se aviene muy bien con la realidad complicada y paradójica del hombre moderno. Por eso la nueva visión de Dios, tal como la comienza a presentar Guillermo de Ockam va a ser mucho menos racionalista, mucho más agustiniana, y con un sentido de la libertad que no se deja domesticar por el hombre y mucho menos por falsos dioses. «Y este Dios, ockamista, más auténticamente cristiano, más pauliniano y más agustiniano que el Dios un poco paganizado, aristotelizado de santo Tomás, era un Ser tremendo, magnífico, fiero, cuyo primer atributo -el más auténtico en Dios cuando es de verdad Dios y no se ha tenido la avilantez de querer domesticarlo como si fuera un león de Libia o un tigre de Hircania- es la arbitrariedad. Dios es voluntad libérrima, potentia absoluta, sólo coartada por el principio de contradicción, gracias a un último respeto 'racionalista' que de estos hombres, aun los más decididos, como Ockam, guardaban a la Lógica. Puestos a hablar de Dios, nosotros no guardaríamos ese respeto a la Lógica, que viene a ser otra diosa coercitiva de Dios, puesta a su vera con antipático talle de institutriz, para no permitirle contradecirse, con lo que se deja en la idea de Dios un postrer saborete de politeísmo y paganidad» (VIII, 262263, 1947). El Dios cristiano no deja dormir a los profesores de Lógica y por eso ha habido que quitarla de los planes de estudios. Por lo demás, como no toda teología viene del cielo, cuando el mundo social no quiere cambiar, una teología que se precie, tampoco cambia, y menos de forma escandalosa, porque eso sería perder el buen tono social que tanto ha cultivado cierta teología y sus aledaños eclesiásticos. 


\section{San Agustín, Descartes y el hombre moderno}

En varias ocasiones se plantea Ortega la relación entre san Agustín y Descartes. Siempre afirma que alguna coincidencia hay entre ambos pero que esa relación no puede considerarse como una influencia directa. En cada momento aprovecha Ortega para subrayar distintos aspectos que él quiere destacar. En el primer texto que vamos a ver quiere dejar bien claro Ortega su lejanía del idealismo cartesiano. Dice así: «El genial descubrimiento de Descartes - palpado ya por san Agustín y san Anselmo, pero sólo palpado- consiste en haber advertido que 'hay algo cuya existencia relativa a mí y su existencia absoluta son idénticas, o dicho de otro modo, que hay algo cuya existencia absoluta consiste en existir en mí o en mi creencia de que existe» (XII, 121, 19321933). Para Ortega, Descartes dice que 'existo en absoluto' y ese absoluto es mi pensamiento (XII, 123). Entonces, dice Ortega, sólo hay pensamiento. Adiós, pues, a todo lo demás. En cambio, para Ortega la realidad es coexistencia, vivir es convivir, y todo conocimiento es una coexistencia entre el yo y la circunstancia (XII, 126).

Ortega quiere detallar en qué consiste realmente el descubrimiento que ha hecho Descartes, apoyado en la tradición cristiana, y que le ha convertido en padre de la modernidad. Para Ortega: «El que crea que Descartes inaugura nada menos que la Edad Moderna, por habérsele ocurrido esa chilindrina de que no podemos dudar de que dudamos, en que también había caído san Agustín, no tiene ni la más ligera sospecha de la enorme innovación que representa el pensamiento cartesiano, y, en consecuencia, ignora de raíz lo que ha sido la modernidad» (VII, 366, 1929).

Por una parte Descartes ve que de la duda no se puede dudar porque si no ya no sería duda. Y por otra parte Descartes ve que el pensamiento no tiene del universo más que el pensamiento mismo. El pensamiento es la realidad y viceversa, y esto separa a la Modernidad de todo el mundo anterior como una gran muralla China universal (VII, 367, 1929). Ahora el pensamiento y la subjetividad humana se tornan en el punto clave del universo por ser lo único que, de verdad, tenemos y sabemos. Así que la Edad Moderna tiene hambre tanto de realidad como de intimidad y de personalidad real.

El hombre, en la Modernidad, se queda solo, no tiene más que soledad. La soledad es la esencia del hombre moderno. De ahí ese hambre de realidad que le lleva a confundir el mundo con Dios, la materia con el espíritu, la economía con la cultura. Desde aquí vuelve Ortega a san Agustín. Porque, según Ortega, sólo bajo la especie de soledad se encuentra el alma, el hombre, con su auténtico ser. Para el cristiano, no para la filosofía, así llamada cristiana, que no pasó de ser una soga triste y estéril del cristianismo, no hay más realidad que Dios y el alma. «No hay más que esa doble realidad: Dios y el alma- y como conocimiento es siempre para el cristiano conocimiento de lo real, el co- 
nocimiento ejemplar será el de Dios y el alma. Así, san Agustín: Deum et animam scire cupio. Nihilne plus? Nihil omnino. No es casual que sea san Agustín el primer pensador que entrevé el hecho de la conciencia y del ser como intimidad, y tampoco lo es que sea el primero en caer en aquello de que no se puede dudar de que se duda. Es curioso que el fundador de la ideología cristina y el fundador de la filosofía moderna coincidan en toda su primera línea. También para san Agustín el yo es en cuanto se sabe ser - su ser es su saberse - y esa realidad del pensamiento es la primera en el orden de las verdades teoréticas. En esa realidad hay que fundarse, no en la problemática realidad del cosmos y lo externo. Noli foras ire, in te ipsum redi, in interiori homine habitat veritas. Aquí está también el hombre como absoluto interior, como intimidad. Y, como Descartes, en el fondo de esa intimidad encuentra a Dios. Es curioso que todos los hombres religiosos coincidan en hablarnos de lo que también santa Teresa llama 'el fondo del alma'; y que sea justamente en ese fondo del alma donde, sin salir de ella encuentran a Dios. El Dios cristiano, por lo visto, es trascendente al mundo, pero inmanente al 'fondo del alma'. ¿Hay alguna realidad bajo esta polvorienta metáfora? No interroguemos ahora lo que ahora no podemos contestar» (VII, 386, 1929).

Ortega insiste decididamente en precavernos de que sería «injusto y falso afirmar que Descartes está ya en san Agustín» (VII, 386, 1929). Y que las mayores coincidencias no hacen más que señalar aún más las distancias. Para Ortega, en san Agustín, perdura aún - a pesar de que es un hombre modernola antigua actitud un tanto caótica; por eso san Agustín es un Padre de la Iglesia, principalmente, y no un clásico de la filosofía, sobre todo. Ortega lo ve así: «San Agustín era un genio de la sensibilidad religiosa; por su intuición religiosa llega san Agustín a descubrir el ser reflexivo- como filósofo procura definir su intuición y situarla en el lugar que le corresponde dentro de la ciencia, pero como no es un gran filósofo, que es lo que era Descartes, le falta del golpe de vista genial que lleva a éste a volver del revés toda la ideología antigua y fundar el idealismo moderno» (VII, 386, 1929).

Ortega admite también que aunque no esté demostrada la influencia directa de san Agustín en Descartes es lo mismo. La idea de conciencia que 'aflora en san Agustín' va madurando en la Edad Media aunque en una línea no muy estimada por la escolástica triunfante: «Se puede reconstruir perfectamente la cadena de transmisión desde san Agustín hasta Descartes - pasando por san Bernardo de Claraval, por los victorinos, san Buenaventura y los franciscanos, Duns Scoto, Ockam y Nicolás de Autrecourt. En este camino la idea de conciencia no ha tenido más que un tropiezo: santo Tomás de Aquino, que abandona esta idea de origen cristiano para volver al alma cósmica de Aristóteles, sometiendo de nuevo la original inspiración del Cristianismo al molde incongruente del pensar antiguo. La modernidad nace de la cristian- 
dad; ique no se peleen las Edades, que todas sean hermanas y bien avenidas!» (VII, 387, 1929).

Por otra parte no hay que tomar a mal la 'desviación' de santo Tomás ya que puede ser hoy provechosa en un sentido ecologista y sanamente naturalista ${ }^{8}$.

Ortega tiene un gran interés - primero en el caso de san Agustín y Descartes y luego por el mismo caso de Ortega y Dilthey - en que cuando analicemos la influencia de un autor sobre otro no haya precipitación en ver, por todos los lados toda clase de parecidos. Con frecuencia, según Ortega, esa influencia y ese parecido no existe sino únicamente para el que lo ve así que, por consiguiente, tiene un nuevo nivel de experiencia intelectual y humana. Eso es lo que ocurrió con el tema de la evolución y lo que ocurre, según Ortega, en el descubrimiento de la idea de vida y su aplicación al estudio de la historia por Dilthey y por el mismo Ortega. Varios hombres están viviendo en el mismo nivel aproximado de experiencia humana y del mundo. Lo que hay de común entre ellos, sin necesidad de influencia directa de unos sobre otros, es la comunidad «de nivel en la escala de experiencias intelectuales y humanas» (VI, 168, 1933-1934).

Esto es lo que ocurre también, según Ortega, en el descubrimiento del Cogito, del yo y de la duda por Descartes con respecto a san Agustín. Para Ortega, lo que influye realmente de uno en el otro es la continuidad del cristianismo y lo que supone en ambos la gran experiencia humana que ese cristianismo es también. «Pero, claro está, (nos dice Ortega) ese cristianismo 'fuente' de Descartes no es san Agustín ni san Anselmo, ni mucho menos esta o la otra idea particular de ningún Padre de la Iglesia. En cambio, hablar de san Agustín como fuente sensu stricto del Cogito, que es una tesis particular, si bien decisiva en el cartesianismo, resulta ridículo, y lo será tanto cuantas mayores coincidencias literales se encuentren. Bastaría para rechazar esa filiación hacerse cargo de que las frases de san Agustín estaban ahí desde hacía trece siglos patentes a todos, sin que de esa fuente manase el Cogito - iqué casualidad! - hasta el decenio de 1620». (VI, 169, nota, 1933-1934).

Añade Ortega, en ese mismo pasaje, que la influencia de Aristarco de Samos en Copérnico y de san Agustín en Descartes y sus descubrimientos son prácticamente nulas. Eso parece algo objetivamente cierto. Pero tampoco deja de ser una casualidad, interesante, que san Agustín dijera lo que dijo, tan parecido a Descartes, y que se le haya nombrado después como el primer hombre moderno, siendo a su vez Descartes el padre de la modernidad según reconoce Ortega. Y, sin embargo, es cierto que distintos autores coinciden en lo

8. SCHILlEBEECKX, E., Cristo y los cristianos. Gracia y Liberación, Cristiandad, Madrid $1982,172-185 ; 716-718 ; 789-798$. 
mismo sin influencia alguna mutua -y eso beneficia también la imagen de Ortega - como parece que ocurrió en el caso de la aparición de la teoría de la evolución que se descubrió por varios autores a la vez sin una gran influencia directa de unos en otros.

No obstante, el caso de san Agustín y Descartes se ve que le merece a Ortega una atención especial y hace de él una última valoración al final de su obra: La idea de principio en Leibniz y la evolución de la teoría deductiva. Se trata del pasaje siguiente: (VIII, 319-320, 1947). El resumen del mismo podría declararse así:

-Es incuestionable que algunas ideas fundamentales de Descartes coinciden 'una a una' con otras de san Agustín (VIII, 319). Pero no se ha podido demostrar procedencia estricta porque cuando vemos el tramado que cada uno hace, como los mismos mimbres, muchas de las supuestas coincidencias se desvanecen- No obstante, no hay que escatimar ni las coincidencias ni las divergencias entre ambos pensadores. Por consiguiente hay que ver en cada caso lo que ocurre porque puede haber más o menos coincidencia de lo que parece. -Es también un hecho que la escuela cartesiana se nutrió ampliamente de autores agustinianos-. Coincidencias y divergencias hay en el tema de la iluminación: En san Agustín procede de Dios, en Descartes del lumen naturale (VIII, 319, 1947), si bien hay también según Descartes un nescio quid divini (VIII, 320, 1947). Y Descartes, a pesar de todo, da a Dios una gran intervención en el hecho (VIII, 320, 1947) lo que introduce, paradójicamente, un elemento de cierta irracionalidad en el sistema del fundador del racionalismo. También ocurre que en ambos además de conciencia hay algo más por lo que toda conciencia es coexistencia y en todo conocimiento parece haber 'yo y mi circunstancia'. Ofrecemos el texto completo, aunque sea un poco largo, para que el lector juzgue por sí mismo. Dice así: «Es incuestionable que algunas ideas fundamentales de Descartes coinciden, una a una, con otras de san Agustín. Pero la verdad es que no ha podido probarse persuasivamente el origen agustiniano de las ideas de Descartes, porque esa palmaria coincidencia, que tomadas una a una manifiestan, se desvanece cuando las tomamos articuladas unas en otras, por tanto, en su intención, movimiento, trama y resultado. Parece, pues, tan infértil escatimar el reconocimiento de la coincidencia como desatender los momentos diferenciales que cada una de esas ideas tiene en ambos pensadores. Más interesante juzgo el intento de definir en qué caracteres el estilo intelectual de uno y otro se asemejan, porque llevaría no sólo a explicar aquellas coincidencias, sino a ampliar mucho más el paralelismo entre ambos, es decir, a mostrar cómo 'coinciden' también en no pocas otras cosas en que aparentemente no coinciden y, en fin, a ilustrar el hecho notorio de que la escuela cartesiana resultase nutrida, en las generaciones inmediatas, precisamente por agustinianos. Un ejemplo de eso que he llamado coincidir en lo 
incoincidente puede hallarse en este mismo y decisivo punto de la adquisición de la verdad por el hombre. San Agustín y Descartes llaman al hecho en que se adquiere 'iluminación'. Pero en san Agustín la iluminación que es el acto inte ligente no procede del hombre, sino que es una operación de Dios en éste (De CivitateDei, VIII, c. 5), al paso que, según Descartes, la iluminación intelecti va es una acción del lumen naturale, si bien a la vez nescio quid divini *, que el hombre posee, más aún, que es el hombre en su última mismidad. El lumen naturale es una expresión transmitida a los modernos por Cicerón y que ése debió encontrar en los estoicos, para los cuales tenía pleno y jugoso sentido, mientras que en Descartes no lo tiene,1(c2 0lrl(v32d0lor2a0loVrormcKK3(r2uv(2,01(ro(2i01)(ol((c2e)01(o2n0) 
blación europea anda buscando dictadores y que alguna nación europea ya ha encontrado el suyo al que las masas ceden su vida, su alma y su responsabilidad - el gran problema de Goethe es que no ha atendido a su vida fundamental, a lo más profundo de sí mismo, por lo cual el gran escritor se falsificó a sí mismo en tareas eruditas, como han hecho también sus biógrafos, y se perdió en el mundo social al aceptar cargos de poder en Weimar (IX, 597, 1949).

Todos los hombres corremos este gran peligro de falsificarnos a nosotros mismos, de olvidarnos de lo principal en nuestra vida, ser fieles a nosotros mismos, a lo mejor que cada cual lleva dentro y que se define por la vocación. Hacer otra cosa que no fuera ser fieles a nosotros mismos, a nuestra vocación, a nuestra misión y destino, sería deshacerse y chantajearse a sí mismo, desvivirse, sobornar la propia conciencia vital y no ser el que tenemos que ser y podemos realmente ser. Así el hombre se pierde a sí mismo, pierde su vida, se desfonda y pierde lo más profundo de sí (IV, 422; 425, 1932), falsifica su propia vida y practica un 'suicidio en blanco'. El que no sigue su vocación -nos dice Ortega - no es el que tiene que ser, se deshace de su vida y se convierte en un suicida en pie.

En este terrible peligro, san Pablo, según Ortega, al invitarnos a la conversión - metanoeite - nos llama a no abandonarnos, a convertirnos a nosotros mismos, a cada uno le avisa para que vuelva en sí, a su vida mejor y más profunda, a su verdadero ser, y a todo eso llama Ortega ensimismarse; por eso, dice él, que san Pablo tiene plena razón: « $Y$ no hay duda que esa voz 'convertíos' o como yo prefiero decir 'ensimismaos', buscad vuestro verdadero yo, es la que hoy otra vez urgiría dar a los hombres- sobre todo a los jóvenes» $(\mathrm{V}, 116,1933)$. Ortega ve venir el problema de Alemania, cómo los hombres entregan su vida, su alma, al gran dictador y avisa a los jóvenes porque hoy todo el mundo quiere que le engañen para falsificar su vida, alterarla, alienarla, y entregarla a un falso ideal. Ante esta manía de las masas Ortega hará un largo silencio porque no está dispuesto a ser el hombre al que las masas, particularmente las juveniles, buscan para que les engañe; y porque además para un intelectual pura sangre como él permitirse el lujo de engañar sería un gran crimen contra sí mismo.

Tal es la situación del hombre actual. Es así cómo el hombre se deforma a sí mismo y destruye su auténtico ser. La conversión es lo único que puede impedir ese trágico destino o tremendo acontecimiento. Sólo, de este modo, puede el hombre dejar de eludir su ser más profundo y convertirse a sí mismo y desde ese ser de sí mismo, encontrar a Dios. Ortega utiliza muy claramente la experiencia agustiniana del 'hombre interior' y de la 'gran profundidad' para hablar del hombre auténtico y de su realización en la vocación personal que encierra también una gran misión social. Ya nos hemos encontrado varias ve- 
ces con este fondo insobornable del hombre. Hay que vivir, pues, a fondo para llegar a vivir en plenitud.

En cuanto a la necesidad de una nueva y constante formación humana y de una vida del hombre en plenitud o en plena forma también nos habla de ella Ortega de una manera muy clara. Según Ortega, no hay seres nobles y plebeyos que a cada uno se atribuyeran previamente, ni seres selectos $u$ hombres masa que fueran concedidos a unos u a otros seres arbitrariamente, es cada uno el que decide lo que será. Si lucha por una vida en plenitud, en plena forma, será un hombre auténtico, egregio, selecto, será en definitiva él mismo, de lo contrario se dejará arrastrar fácilmente a lo peor. La religión consiste precisamente en religere y eligere -en religarse y elegir- en vez de ser negligente - negligere - de sí mismo y de su propia vida. Ortega dice todo esto en un pasaje que es también decisivo para saber lo que entiende, realmente, Ortega por minorías y por masas. Dice así: «A las minorías selectas no las elige nadie. Por la sencilla razón de que la pertenencia a ellas no es premío o una sinecura que se concede a un individuo, sino todo lo contrario, implica tan sólo una carga mayor y más graves compromisos. El selecto se selecciona a sí mismo al exigirse más que a los demás. Significa, pues, un privilegio de dolor y de esfuerzo. Selecto es todo el que desde un nivel de perfección y de exigencias aspira a una altitud mayor de exigencias y perfecciones. Es un hombre para quien la vida es entrenamiento, palabra que, como he hecho notar en recientes conferencias, traduce exactamente lo que en griego se decía ascetismo. (El ascetismo, áskesis, es el régimen de vida que seguía el atleta, lleno de ejercicios y privaciones constantes para mantenerse en forma. Este vocablo tan puramente deportivo es acaparado luego por los cenobitas y monjes y pasa a significar la dieta del hombre religioso, resuelto a mantenerse en estado de gracia, esto es, en for$m a$, para lograr el premio de la beatitud» (IV, 487-488, 1924).

Sin esta plenitud de forma, el hombre se vuelve canalla, soborna su conciencia vital y destruye su fondo insobornable, deja, finalmente, de ser él mismo y se entrega a la vida de la masa, al encanallamiento y a la vida informe e informal, pierde el sentido y se deshumaniza. Entonces vemos por qué la vida en forma, según la propia misión, vocación y destino es el todo del hombre. De ahí que, nos dice Ortega: «Lo más interesante no es la lucha del hombre con el mundo, con su destino exterior, sino la lucha del hombre con su vocación. ¿Cómo se comporta frente a su inexorable vocación? ¿Se adscribe radicalmente a ella, o, por el contrario, es un desertor de ella y llena su existencia con sustitutivos de lo que hubiera sido su auténtica vida? Tal vez lo más trágico en la condición humana es que puede el hombre intentar suplantarse a sí mismo, es decir, falsificar su vida. ¿Se tiene noticia de ninguna otra realidad que pueda ser precisamente lo que no es, la negación de sí misma, el hueco de sí misma?» (IV, 402, 1932). 
La vocación es 'una voz extraña' emergente de no sabemos qué 'íntimo y secreto fondo nuestro', la cual nos llama a lo que tenemos que ser. Y sólo vive de verdad el que vive su vocación y así coincide con su verdadero 'sí mismo'. «Éste es el ingrediente más extraño y misterioso del hombre. Por un lado es libre: no tiene que ser por fuerza nada, como le pasa al astro, y, sin embargo, ante su libertad se alza siempre algo con carácter de necesidad, como diciéndonos: 'poder puedes ser lo que quieras, pero sólo si quieres ser de tal determinado modo serás el que tienes que ser'. Es decir, que cada hombre, entre sus varios seres posibles, encuentra siempre uno que es su auténtico ser. Y la voz que le llama a ese auténtico ser es lo que llamamos 'vocación'. Pero la mayor parte de los hombres se dedican a acallar y desoír esa voz de la vocación. Procura hacer ruido dentro de sí, ensordecerse, distraerse para no oírla y estafarse a sí mismo sustituyendo su auténtico ser por una fasta trayectoria vital ( $V$, $138,1933)$.

Una vida así es una vida des-nortada, des-orientada, es una vida absolutamente informal, carece de verdadera forma $y$, por supuesto, de la plenitud de forma que el hombre en el fondo desea y se queda en una vida fundamentalmente deformada. San Agustín nos advierte de esa terrible posibilidad. Pues así el mundo sería una deformidad (Confesiones, XII, II, 2; y XII, III, 3; y XII, IV, 4 y XII, VI, 6). Es Dios quien nos llama a dejar esa vida in-forme (Confesiones, XIII, II, 2) y si no lo hacemos nos des-atendemos a nosotros mismos y terminamos por deformarnos completamente ${ }^{9}$.

Según san Agustín, Cristo es nuestra auténtica forma y nos cura de nuestra deformación cuando nos convertimos a Él e imitamos su 'forma sempiterna' (De Genesi ad litteram, I, IV, 9). Entonces la imagen de Dios se rehace, por medio de Él, en nosotros. Dios es la forma auténtica, verdadera, original, del hombre (Confesiones, XIII, XXII, 32) y a Él debemos con-formarnos para re-formar nuestra vida guiados por su Espíritu y por su imagen, puesta por Él en nosotros. Ciertamente nadie puede decir «no puedo», no puedo reformarme (Confesiones, X, III, 4). Nadie puede decir que no puede convertirse o que no puede mejorar y ser realmente mejor, pues Dios mismo ha venido en nuestra ayuda para ponernos en forma y rehacer su imagen en nosotros, y así reformar lo que Él mismo había formado: «El verdadero honor del hombre consiste en ser imagen y semejanza de Dios, y sólo el que la imprimió puede custodiarla» ${ }^{10}$.

En fin, valga este rápido apunte sobre vocación y conversión en san Agustín y Ortega por una exposición más amplia que otros harán mejor. Orte-

9. CuÉllar BASSOLS, L., Verdadera y falsa autenticidad vital. Confrontación crítica de dos actitudes: Ortega y san Agustín, Convivium, 1 (1956) 55-74.

10. De Trinitate, XII, XI, 16: «Honor enim hominis verus est imago et similitudo Dei, quae non custoditur nisi ad ipsum a quo imprimitur». Subrayado nuestro. 
ga ha bebido sin duda en profundas fuentes agustinianas a través de algunas obras fundamentales de san Agustín, y de algunos autores fundamentales, particularmente alemanes, como los ya citados Max Scheler, Mausbach, Geyser, Schneider, R. Otto y Przywara, entre otros, y eso se puede notar a lo largo de la Obra de Ortega, como hemos tratado de hacer ver aquí. Parece que el acercamiento de Ortega a san Agustín es mayor a partir de 1930 y particularmente en la parte final de su vida. Don Gregorio Marañón, tan cercano siempre a Ortega, lo recordaba en el homenaje a Ortega, en la Universidad de Madrid, al mes siguiente de su muerte, según hemos dejado dicho. Ortega, dentro de su sentido general de que España era el problema y Europa la solución, ha mirado a san Agustín como genio de Europa y a la herencia agustiniana europea y ha encontrado en ella respuestas fundamentales a los graves problemas del hombre de su tiempo y, al parecer también, a los suyos propios personales. No era en vano que la revista agustiniana Religión y Cultura encomiaba, sin reparo alguno, la obra de Ortega con ocasión de publicarse sus Obras completas en 1932; volvía a defenderle en 1958 contra la opinión religiosa entonces más generalizada e incluso el director de esa revista agustiniana, antes citada, acudiría a la Nunciatura con un profesor jesuita y un sacerdote universitario para evitar la condena de Ortega y la posibilidad de poner sus escritos en el Índice de libros prohibidos por la Iglesia, cosa que afortunadamente, estos buenos hombres consiguieron evitar ${ }^{11}$.

Para terminar recordemos que el hombre actual sigue respirando, en su ser más profundo, por la herida del corazón agustiniano. Es cierto que vivimos, de nuevo, tiempos agustinianos, «tiempos de decadencias imperiales y de desencantos políticos. De dualismos maniqueos y de humanismos pelagianos. De sectarismos donatistas y de escepticismos académicos. Tiempos de muchos ruidos y de poco silencio. De muchas prisas y de poca interioridad. De muchas instancias confusas y de pocas referencias trascendentes» ${ }^{12}$.

En efecto, el hombre de hoy se cree tan autosuficiente como el viejo pelagiano. Es tan dualista como el viejo maniqueo: el malo es siempre el otro, nos dice la Nueva Filosofía cuando describe lo que el honbre actual piensa de sí mismo y de los demás. Los sectarismos han aumentado: la ortodoxia dura y el nuevo mester de progresía se creen dueños absolutos de la verdad, cada uno por su parte. Que falta interioridad e instancias últimas transcendentes lo sabe todo el mundo y resulta casi inútil y antipático repetirlo. Por eso se ha caído

11. Todo este asunto puede verse, con detalle, en la parte final de mi tesis doctoral, de próxima aparición, NATAL, D., Ortega y la religión. Nueva Lectura. Durante su elaboración pudimos recoger todos los textos relativos a san Agustín que aquí citamos.

12. Rubio, P., Presentación en SAn Agustín, Confesiones, BAC, Madrid 1986, 17. Traducción de José Cosgaya García, OSA. 
en el escepticismo. Para distraer y despistar el problema, el hombre trata de ensordecerse a sí mismo, como nos decía Ortega. De ahí que haya mucho ruido y pocas nueces.

Paralelamente a esta situación, la experiencia filosófica actual tiene resonancias típicamente agustinianas en sus figuras más señeras. Nos lo dirá perfectamente el gran centinela cultural europeo, el polaco, Erich Przywara, con una descripción amplia pero, todavía hoy, insuperable: «Como se ve, la actualidad es una situación típicamente agustiniana. Lo advertimos con seguridad en las direcciones positivas que surcan el pensamiento fenomenológico y desde ese punto de vista pueden perfectamente calificarse de neoagustinismo. El pathos fundamental de la 'verdad' en la 'intuición', propio de Husserl, es uno de los hálitos básicos para Agustín: 'Mira, contempla si puedes: Dios es' (De Trin VIII, 2,3). El pathos fundamental del valor en el amor, dentro de la sociedad propio de Scheler, deriva de aquello que para Agustín es la faz viva del Dios-Verdad: 'Breve, en una palabra, se expresa la alabanza de Dios nuestro Señor: bueno es el Señor' (in Ps 134,3): 'Esto es bueno y aquello es bueno; quita esto y aquello, y verás a Dios, como él es, bien de todo bien' (De Trin VIII, 3,4). Finalmente, no cabe duda de que Heidegger pinta tan crudamente la nada y desazón evolutivas de la criatura porque en él alienta el pathos fundamental de Agustín: est... quaero, 'es decir... yo busco' (In Ps 38,7).

En todo esto lo más evidente y profundo agustiniano es el radicalismo con que todo lo apariencial es reducido a lo 'propio'. Husserl adopta una postura agustiniana cuando se retira del mundo exterior de lo sensorial a lo interior del espíritu, y de lo contingente del mundo material a lo eterno y necesario del mundo de las esencias. Eso es lo que siempre repetía Agustín: 'Concéntrate dentro de ti mismo' (In Job 23,10), dentro del espíritu hasta llegar a las razones esenciales, pasando de la mens a las rationes rerum, no es menos agustiniana la actitud de Scheler, cuando con su teoría del valor y de la sociedad trata de reducirlo todo a las últimas dos tendencias del amor, una egoísta y demoledora, otra social, creadora y benéfica. Precisamente, èl tema de La Ciudad de Dios aduce esas dos tendencias del amor como razón primordial de las 'dos ciudades'. Es finalmente muy agustiniana la disposición con que Heidegger arranca de la aparentemente firme realidad cotidiana al hombre satisfecho, para lanzarlo a la inquieta preocupación y angustiada inquietud de un secreto y constante desafío con la nada. En efecto, es el pensamiento favorito de Agustín el que recobra vida aquí: 'El ser que propiamente no es, es el ser creado' (In Ps 38,7). Es la desazón, la caducidad de la vida como muerte».

Tampoco se ha de pasar por alto que la brusca dinámica que da al radicalismo contemporáneo tan característico ritmo, lleva un evidente sello agustiniano. Bien lo advertimos en esa 'búsqueda del infinito' que marca el horizonte de la fenomenología de Husserl, que lleva a la teoría de la intencionalidad 
emocional de Scheler hacia nuevos aspectos fulgurantes, y que en la ontología de Heidegger constituye la esencia de esa caducidad en que consiste el ser, por lo que da pie para una mentalidad aporética. En esa 'búsqueda del infinito' palpita la 'inquietud' inquietum... cor (Conf. I, 1,1), 'atormentada' stimulis internis (Conf. VII, 8,12) de la 'criatura efímera' de Agustín (De Trin II, 6,8). En ella palpita y vibra la creciente ansiedad de la criatura (In ep. Joh 4,6) y, por consiguiente, el perpetuo 'buscar para encontrar, pero encontrar para seguir buscando' (In Joh 63,1)» ${ }^{13}$. Eso es todo y el todo... agustiniano.

\author{
DOMINGo NATAL Álvirez \\ Estudio Teológico Agustiniano \\ Valladolid 1987
}

13. Przywara, E., San Águstín. Perfil humano y religioso, Cristiandad, Madrid 1984, 8687. Traducción de Lope Cilleruelo. 